Article

\title{
Decision Making System in Choosing Poultry Medication at PT.Avindo PBM Web-Based Using Forward Chaining
}

Zanuar Gunawan1, Rudy Arijanto2,

1, 2 Buddhi Dharma University, Information Systems, Banten, Indonesia

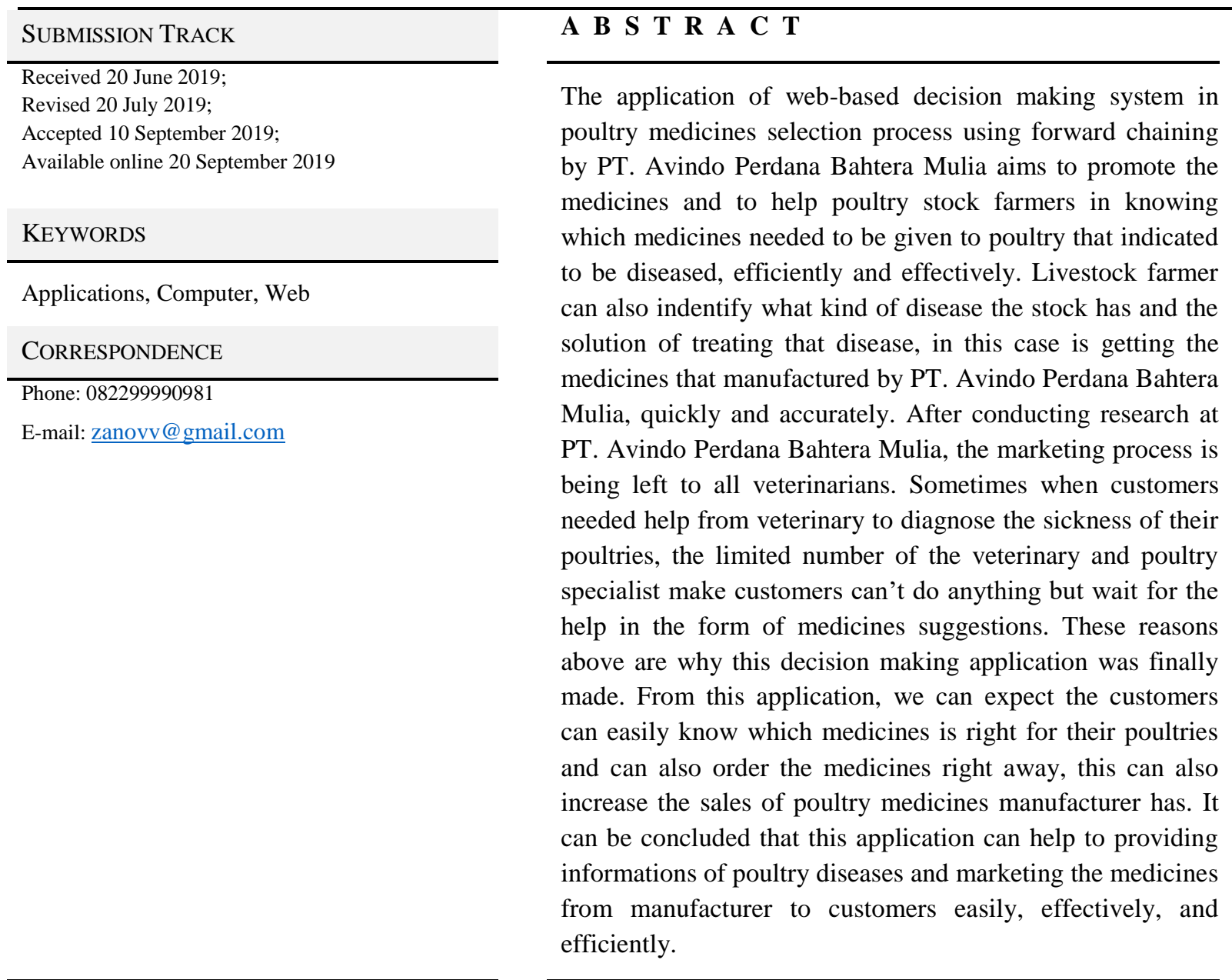




\section{PRELIMINARY}

The information system is an organized association of data along with procedures for its use which covers more than just the presentation. The term implies a purpose to be achieved by selecting and organizing data as well as set up protocols for its use [1][2].

In the current era of industry poultry veterinary drugs is growing rapidly, considering the many types of diseases and medicines required to cope with the disease, some communities that have poultry have difficulty in knowing the type of drug to treat a disease suffered by poultry

So also with the people who are able to easily access information through the Internet, but finding information on the Internet is certainly not enough to help in the search for a suitable drug for poultry diseases due to lack of more knowledge about the types of diseases that exist and should consult back to the experts, but to bring in an expert on farm costs and time are not little because almost all the cattle are in rural locations.

Of these issues, PT. Avindo Perdana Bahtera Mulia wants to realize the information system in the form of decision-making system that is intended to help the poultry farmers in determining the appropriate medication indicated for livestock diseases and also help market the drug in a way that modern so that medicines manufactured by PT.Avindo can be easily accessible by farmers in the city or outside the city, the solutions provided in the form of medicines produced by PT.Avindo Perdana Bahtera Mulia accordance with the characteristic symptoms of the disease or diseased poultry.

\section{METHOD}

Methods used include 2 (two) parts, namely data collection methods and design method.

\section{Method of collecting data}

\section{a. Literature review}

This method is used to collect the theories of both general or specifically related to the design application sourced from books, articles, journals and the Internet.

\section{b. questionnaires}

This method was conducted to determine the level of satisfaction of users of the application if the application has been able to address user needs or the need for additional features.

\section{c. Interview}

This method is used to obtain information about the function of each drug in order to fit on any symptom poultry to obtain appropriate conclusions.

\section{Design method}

The design method used is the Decision Support by using forward chaining algorithm. [3] reveals "Forward Chaining is a decision making method commonly used in expert systems. The search process with forward chaining method departs from left to right, from the premise leads to a final conclusion, this method is often called data driven search is controlled by the data provided.

forward Chaining search strategy which initiated the process of collection of data and or fact, of the data sought a conclusion that a solution of the problems faced. The inference engine look for the rules in the knowledge base that premise is in accordance with these data, then of the rules obtained a conclusion. Advanced coherent start the search process with the data that this strategy also called datadriven. The steps involved in creating a rulebased forward chaining as follows:

1. Defining the problem. This stage includes the selection and acquisition of knowledge of the problem domain.

2. Defining input data. Forward Chaining systems require preliminary data for the start of inference.

3. Defining control structure data. Complex applications require additional premise to help control the activation of a rule. 
4. Writing prefix. This phase is to determine whether the system has been capturing domain knowledge effectively in the structure of a good rule.

5. Testing of the system. System Tests conducted with a few rules to test the extent to which the system is running properly.

6. The design of the interface. The interface is one of the essential components of a system. Interface design created together with the creation of a knowledge base.

7. Development of the system. Development system includes the addition of interfaces and knowledge in accordance with the prototype system.

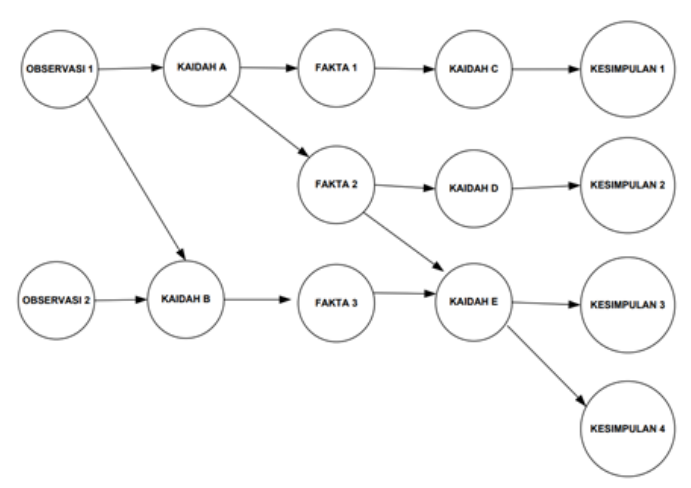

\section{RESULTS}

After doing research PT.Avindo then it may be a solution in the form of Decision Making System In Choosing Poultry Drug Use Forward Chaining initial step in this research is the establishment of rules derived from interviews by experts poultry, the following is a table of the results of the interview:

Table 1. Disease in Poultry

\begin{tabular}{|c|c|}
\hline KP & Disease \\
\hline D01 & Newcastle Disease (ND) \\
\hline D02 & Egg Drop Syndrome (EDS) \\
\hline D03 & Fowl Cholera \\
\hline D04 & Chronic Respiratory Disease (CRD) \\
\hline D05 & Salmonellosis (defecation lime) \\
\hline D06 & Kollibasilosis \\
\hline D07 & Infectious Coryza (Snot) \\
\hline D08 & Ascaris (roundworm) / tapeworm \\
\hline
\end{tabular}

Table 2. Poultry Diseases and Drugs

\begin{tabular}{|c|c|c|}
\hline No. & Disease name & Drug \\
\hline 1 & $\begin{array}{c}\text { Newcastle Disease } \\
\text { (ND) }\end{array}$ & $\begin{array}{c}\text { Calavac Newcastle } \\
\text { Disease Vaccine }\end{array}$ \\
\hline
\end{tabular}

\begin{tabular}{|c|c|c|}
\hline 2 & Egg Drop Syndrome & $\begin{array}{c}\text { Winvac ND vaccine } \\
\text { EDS }\end{array}$ \\
\hline 3 & Fowl Cholera & New-Ox \\
\hline 4 & $\begin{array}{c}\text { Chronic Respiratory } \\
\text { Disease (CRD) }\end{array}$ & Respiroxan \\
\hline 5 & $\begin{array}{c}\text { Salmonellosis (Dirt } \\
\text { lime) }\end{array}$ & Aviflox - 10 -24 \\
\hline 6 & Kollibasiolisis & Coritrime \\
\hline 7 & infectious Coryza \\
\hline 8 & $\begin{array}{c}\text { Ascaris (worm } \\
\text { milled) / Ribbon } \\
\text { Worm }\end{array}$ \\
\hline
\end{tabular}

Table 3. Symptoms In Poultry

\begin{tabular}{|l|l|}
\hline KG & symptom \\
\hline G01 & respiratory Snoring \\
\hline G02 & Diarrhea \\
\hline G03 & Spinning neck \\
\hline G04 & Followed Paralysis Death \\
\hline G05 & $\begin{array}{l}\text { Eggs produced Ugly, eggshell thin or without } \\
\text { shell }\end{array}$ \\
\hline G06 & Pale eggshell color \\
\hline G07 & Under the Wattle Stomach (wattle) distention \\
\hline G08 & Lethargic chicken and Reduced Lunch \\
\hline G09 & There Mucus Thick Of Part and Nose \\
\hline G10 & $\begin{array}{l}\text { White MakeUp Watery Stools, Yellowish, and } \\
\text { Green }\end{array}$ \\
\hline G11 & Stop Hen Egg Production \\
\hline G12 & Cough \\
\hline G13 & Sneezing \\
\hline G14 & Swelling At Home \\
\hline G15 & Chickens Nose Clear Liquid Extract \\
\hline G16 & Chickens often shook his head \\
\hline G17 & Resembling dirt White Colored Chalk (Pasta) \\
\hline G18 & Visible chicken Drowsiness \\
\hline G19 & Loss of Appetite followed Sudden Death \\
\hline G20 & $\begin{array}{l}\text { Chicken "Menciap" Soreness When Remove } \\
\text { Impurities }\end{array}$ \\
\hline G21 & $\begin{array}{l}\text { Chicken Looks Cold and Warm place Tend } \\
\text { Gather }\end{array}$ \\
\hline G22 & Disadvantages Appetite \\
\hline G23 & $\begin{array}{l}\text { Inflammation of the } \\
\text { Network Neighborhood Navel Become Flabby }\end{array}$ \\
\hline G24 & $\begin{array}{l}\text { The release of exudate from the nose and Foul } \\
\text { Smelling }\end{array}$ \\
\hline G25 & Swollen face Because Ederma under the skin \\
\hline G26 & conjunctivitis \\
\hline G27 & Sometimes Difficult Breathing \\
\hline G28 & Blood deficiency \\
\hline v30 & $\begin{array}{l}\text { Weaknesses General and Egg Production } \\
\text { Down }\end{array}$ \\
\hline
\end{tabular}

Phase formation restate the rule is the stage of knowledge required by the system in the form of production rules to get results or conclusions of predefined rules. Knowledge of 
the rules drawn up in Table symptoms based on the knowledge that has been gained.

1. R1 IF G1 AND G2 AND G3 G4 AND THEN P1

2. R2 THEN IF G1 AND G2 P2

3. R3 AND IF G7 G8 G9 AND G10 AND G11 AND THEN P3

4. R4 IF G1 AND G12 AND G13 AND G14 G15 AND G16 AND THEN P4

5. R5 IF G17 AND G18 AND G19 AND G20 AND G21 THEN P5

6. R6 IF G8 AND G21 AND G22 AND G23 THEN P6

7. R7 IF G14 AND G22 AND G24 AND G25 G26 AND G27 AND THEN P7

8. IF R8 G02 AND G08 AND G28 AND G29 AND G30 AND G31 THEN P8

\section{DISCUSSION}

After the search methods and search for information through interviews or literature, the authors convert the data that has been obtained into the decision-making applications using the algorithm forward chaining as an alternative in the search for medicines of poultry more effective and efficient, can be seen in Figure 2 is a display process user input against any symptoms that indicated poultry diseases.

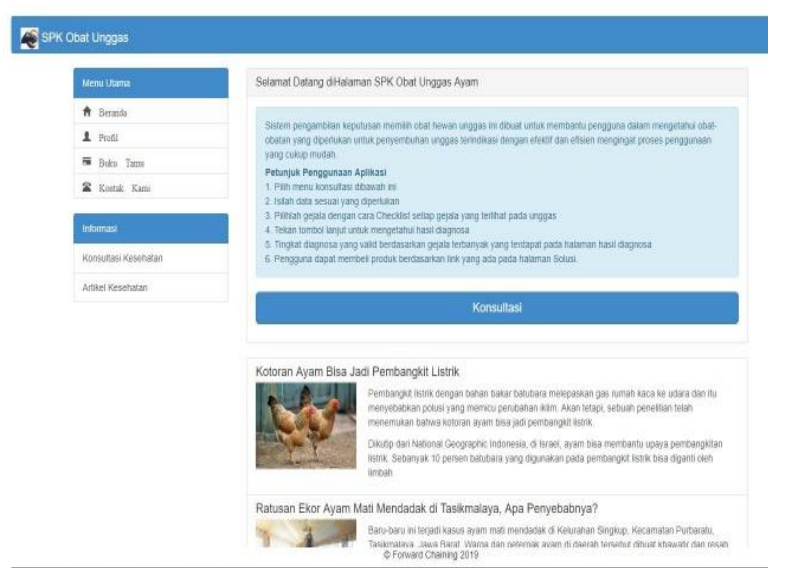

Figure 1: Home

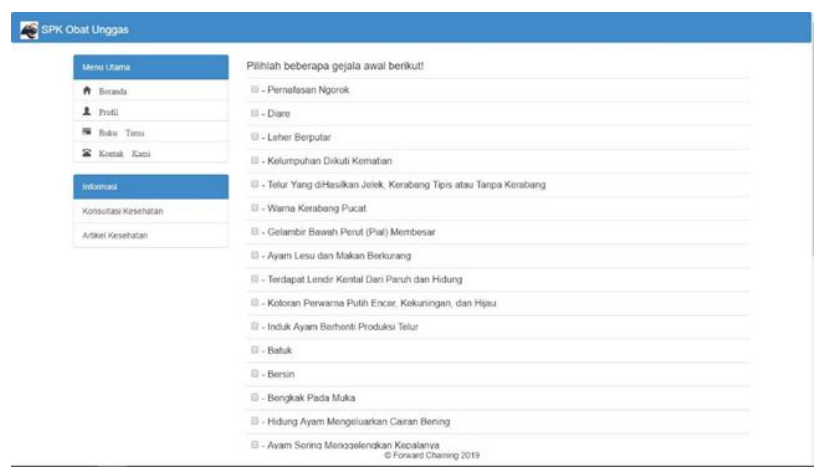

Figure 2: Home Diagnosis

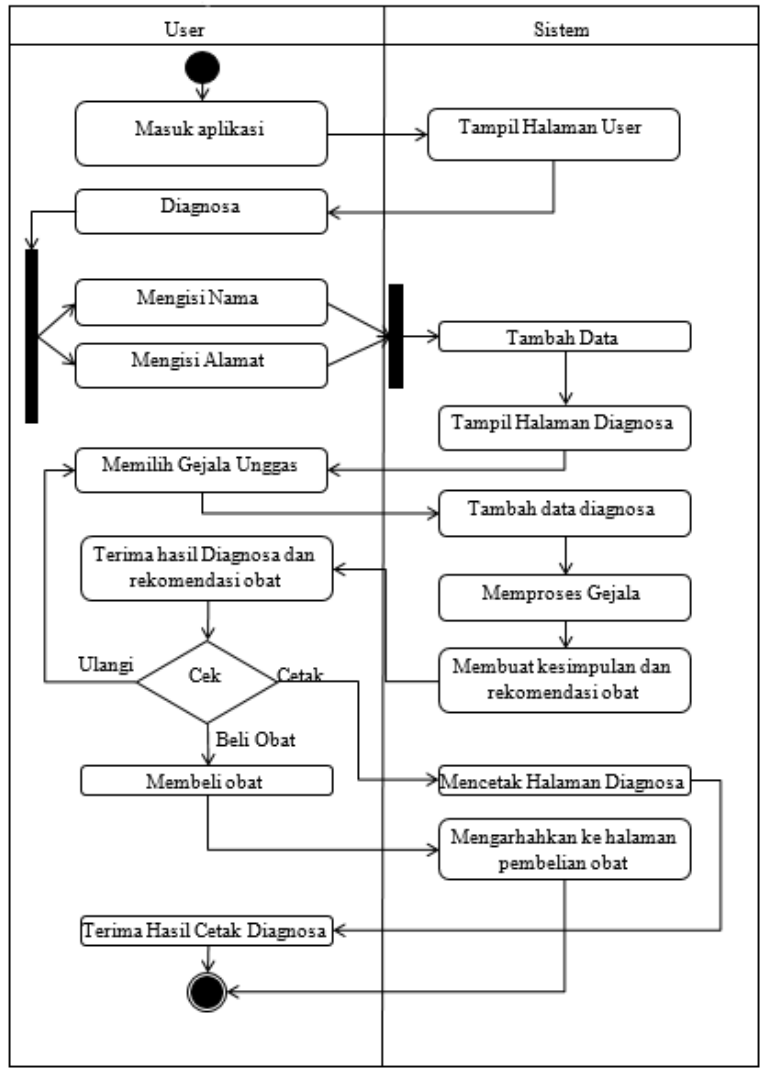

Figure 3: Activity Diagram user 


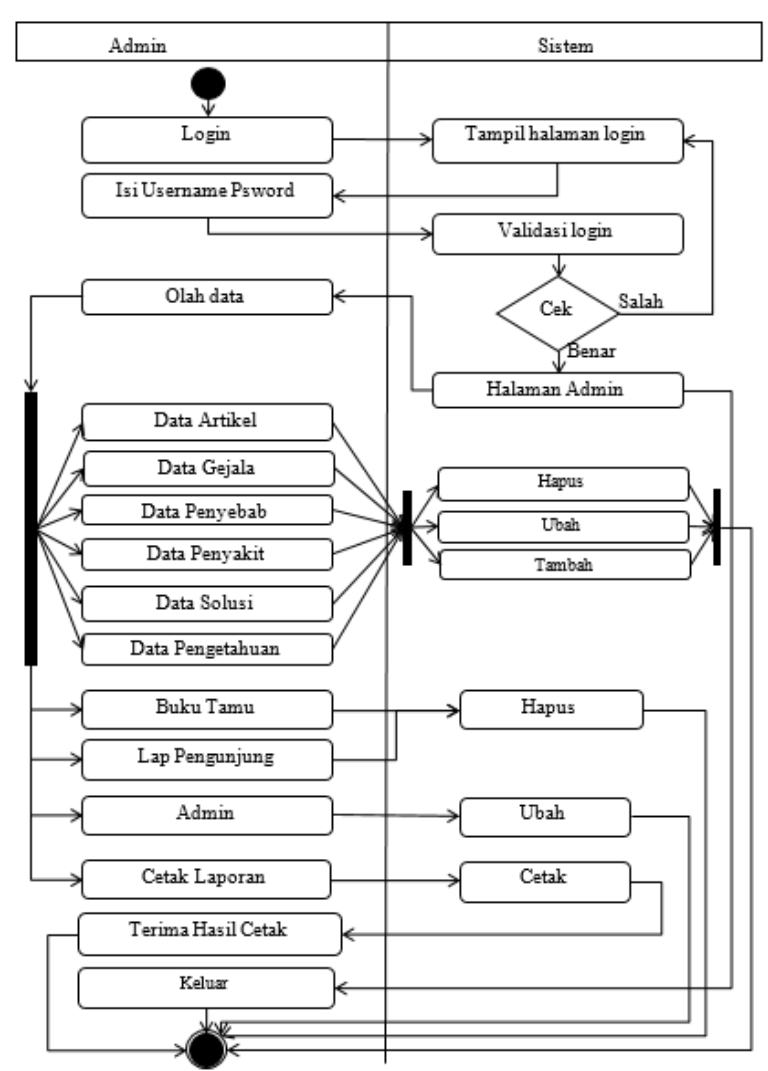

Figure 4: Activity Diagram Admin

IV. CONCLUSION

1. From decision-making system that has been designed and created it can be concluded that this application can work as well to help provide information about animal drugs quickly and precisely.

2. Marketing may have the more extensive time because of its role to diagnose poultry has been aided by this application.

3. PT.Avindo Perdana Bahtera Mulia's products are increasingly popular, and the demand for drugs increased.

\section{REFERENCE}

[1] Al-Fatta, H., 2009. Analisis dan Perancangan Sistem Informasi. Yogyakarta: ANDI.

[2] Yakub, 2012. Pengantar Sistem Informasi. In: Yogyakarta: Graha Ilmu, p. 51:53.

[3] Level Perdana et all, 2013. Sistem Pakar Untuk Diagnosis Penyakit Ginjal Dengan Metode Forward Chaining. JurnalTIkomsin, p. 2.

\section{BIOGRAPHY}

Zanuar Gunawan Graduated in Studies Program Information System (S1), in 2019, work on PT.Avindo Perdana Bahtera Mulia As Accounting since 2016 till now.

Rudy Arijanto Graduated in Studies Program Information Management and Computer STMIK (S1) Bina Nusantara and also Informatics (S2) STTI Benarif, now serving as Dean of the Faculty of Science and Technology at the University of Buddhi Dharma. 